аскорбатоксидазыувеличивается потеря витамина С. Увеличение активности фермента пероксидаза приводит к образованию молекулярного кислорода и перекиси водорода, которая отрицательно действует на процесс получения сахара.

Следовательно, при производстве сахара необходимо создать такие условия, при котором активность ферментов класса оксидоредутаз всегда находилась в форме ингибитора. Для этого рекомендуется хранение сахарной свеклы до переработки в холодильной камере при температуре $+2 \ldots+30$ С и относительной влажности $85-90 \%$. Решение этой проблемы может дать значительные экономические выгоды для производства сахара.

$$
* * *
$$

1. Бугаенко И.Ф. Нанотехнологии в сахарном производстве.// М., Сахар, №3, 2009, стр. 15-18

2. Бугаенко И.Ф. Повышение эффективности сахарного производства./ М., МГУПП, 2008, 180 стр.

3. Бугаенко И.Ф. Принципы эффективного сахарного производства,МСК, Москва, 2003 - 285 стр .

4. Гордеев А.В. Решение проблем продовольственной безопасности.// М., Журнал «Мир агробизнеса» №1, 2008, стр. 4-6.

5. Berghall S., Briggs S., Elsegood S., Eronen L., Kuusisto J., Philip E., Theoblad T., WallianderP.The role of sugar beet invertase and related enzymes during growth, storege and processing.// Zuckerind,122, 1997, pp. $520-530$

\title{
Козлов К.В. \\ Навесные компоненты для гибридной интегральной схемы
} филиал ФГБОУ ВО «НИУ «МЭИ» (Россия, Смоленск)

doi:10.18411/spc-12-04-2018-20

idsp: 000001:spc-12-04-2018-20

В ГИС и микросборках применяются навесные компоненты в случаях, когда данный элемент не может быть реализован по тонкоплёночной технологии или массогабаритные характеристики тонкоплёночных элементов уступают соответствующим характеристикам навесных элементов. Навесные компоненты могут быть в бескорпусном и корпусном исполнении.

Корпусные изделия используются только в микросборках, а в ГИС, как исключение. Чаще всего навесными компонентами в ГИС являются полупроводниковые микросхемы, диодные и транзисторные матрицы, отдельные диоды и транзисторы, миниатюрные конденсаторы и резисторы, трансформаторы и так далее. Особенно выгодным является применение навесных конденсаторов и резисторов большого номинала. Они увеличивают высоту подложки в сборе, но позволяют значительно экономить площадь подложки. При решении вопроса о применении тонкоплёночного или навесного конденсатора, или резистора необходимо произвести расчёт площади, занимаемой тонкоплёночным вариантом элемента, а затем сравнить с площадью, занимаемой миниатюрным бескорпусным элементом того же номинала. Выбор компонентов для конкретной ГИС производится исходя из схемотехнических, конструкторско-технологических требований, требований надёжности, массогабаритных характеристик устройства, условий эксплуатации, сроков освоения, стоимости и т. д. Поскольку надёжность функционирования компонентов определена режимами их работы в схеме, следует учитывать зависимости электрических параметров от условий работы, значений токов, напряжений и мощности.

Выводы бескорпусных элементов могут быть гибкими, балочными, шариковыми, столбиковыми и торцевыми. Недостатком элементов с гибкими и в некоторых случаях с торцевыми выводами является трудоёмкость автоматизации процессов монтажа, так как требуются ручные операции пайки или сварки. Применение компонентов с шариковыми и столбиковыми выводами позволяют 
автоматизировать процесс сборки, но затрудняет контроль качества сборки. Элементы с балочными и торцевыми выводами дорогие, но позволяют автоматизировать сборку, контролировать качество, увеличить плотность монтажа. Способ монтажа компонентов на плату должен обеспечить сохранность формы, параметров и свойств, отвод тепла, стойкость микросхемы к термоциклированию, ударам и вибрации. Для крепления к подложке компонентов используются стёкла с температурной обработкой $450-500{ }^{\circ} \mathrm{C}$, термостойкие клеи на неорганической основе, ситаллы и клеи на основе компаундов. Они не должны разрушать защитные покрытия бескорпусных элементов. Жидкое стекло наносится в виде капли, а затем производится, нагрев печи или установке пайки. Рекомендуется применять эпоксидный клей ВК-9. Крепление приборов может также осуществляться с помощью припоя или эвтектическим сплавом. В этом случае место крепления компонентов на подложке нужно металлизировать. Крепление компонентов с шариковыми или столбиковыми выводами производится в защищённой атмосфере аргона, азота или гелия с применением припоя. Соединение выводов компонентов с контактными площадками производится термокомпрессией, сдвоенным электродом, ультразвуком и пайкой низкотемпературным припоем. Остатки флюса в месте пайки должны обладать изоляционными свойствами и не вызывать коррозии. Резисторы и конденсаторы с торцевыми выводами присоединяются либо пайкой, либо с помощью контактола К13-А.

$$
* * *
$$

1. Ефимов И. Е., Козырь И. Я., Горбунов Ю. И. Микроэлектроника: Проектирование, виды микросхем, функциональная микроэлектроника. -М: Высшая школа, 1987 - 145 с.

2. Коледов Л. А. Конструирование и технология микросхем: учебник. М.: Высшая школа, $1984-231$ c.

3. Николаев И. М. Интегральные микросхемы и основы их проектирования: учебник. М.: Радио и связь, $1992-424$ с.

\section{Козлов К.В. \\ Конструктивные особенности монтажа для элементной базы по направлению тонкоплёночных пассивных элементов гибридной схемы} филиал ФГБОУ ВО «НИУ «МЭИ» (Россия, Смоленск)

doi:10.18411/spc-12-04-2018-21

idsp: 000001:spc-12-04-2018-21

Технология низкотемпературной совместно обжигаемой керамики (LowTemperatureCo-FiredCeramic) используется в различных отраслях промышленности на протяжении многих лет. Усовершенствование LTCC материалов, технологических процессов и методов производства привело к снижению стоимости и улучшению технических характеристик электронных изделий. Это существенно увеличило интерес к LTCC технологии со стороны производителей высокочастотной техники, оптоэлектроники и микроэлектромеханических систем. Новые возможности открываются для производства электронных изделий в таких направлениях как телекоммуникации, медицина, автомобильная, военная и космическая техника. Данная технология активно применяется ведущими производителями для создания компонентов радарных систем, антенн, фильтров и телекоммуникационных изделий. LTCC системы включают в себя полный спектр материалов. Среди них керамический порошок, керамические ленты и листы, пасты для создания внутренних и внешних проводников, пасты для металлизации переходных отверстий, пасты для создания встроенных резисторов. Керамические материалы и металлические пасты подобраны с учётом полного согласования материалов. 